\title{
MODEL AGROMARINE BERKELANJUTAN MELALUI INTEGRASI TEKNOLOGI KARAMBA JARING APUNG (KJA), RUMPON DASAR RAMAH LINGKUNGAN DAN SERO SISTEM KLUSTER DI SULAWESI TENGGARA
}

\author{
La Ode Abdul Rajab Nadia', Abdullah', Amadhan Takwir ${ }^{3}$ \\ ${ }^{1}$ Jurusan Manajemen Sumberdaya Perairan, FPIK UHO \\ ${ }^{2}$ Jurusan Pemanfaatan Sumberdaya Perikanan, FPIK UHO \\ ${ }^{3}$ Jurusan Ilmu Kelautan, FPIK UHO \\ Email: ${ }^{1}$ rajabnadia@yahoo.com; ${ }^{2}$ abdullahsuere04@gmail.com; ${ }^{3}$ awhier@gmail.com
}

\begin{abstract}
Model of agro-marine is a solution for an integrated and sustainable coastal management in coastal communities. The contribution of sero in combination with bottom fish aggregating device (FAD) is important as the supplier of broodstock and diet for fish reared on floating cages. The objective of the present study was to increase aquaculture production sustainably in floating cages and to enhance broodstock production, feed-fish stock and fish consumption harvested by sero and FAD in order to generate integrated business incubation in favor of fish consumption in Southeast Sulawesi. The study was conducted in Staring Bay, South Konawe Regency, Southeast Sulawesi. This study identified broodstock and consumed fish harvested from sero and FAD, the collection of fish to be stocked in floating cages, broodstock adaptation and fish rearing on floating cages, and fish production to reach marketable size. Results showed that there were 1,500 broodstock of Caranx sp., harvested from sero, and 180 broodstock of lobster with the size ranges between 200 and 220 g/individual collected by bamboo fishing trap (bubu) placed in FAD. During the study, the survival of Caranx ignobilis, and lobster reached between $84.25-88.15 \%$ and $92.33 \%$, respectively. The fish were fed fresh trash fish harvested from sero and FAD. The production of fish consumption post harvest ranged from 380.5$560 \mathrm{~kg} / \mathrm{month}$. The agro-marine model contributes to an optimal production and minimizes production cost of aquaculture and also increases fish consumption sustainably.
\end{abstract}

Keywords: agro-marine, production, aquaculture, fish consumption, sustainable

\section{PENDAHULUAN}

Sebagai daerah yang wilayahnya didominasi oleh perairan laut, Sulawesi Tenggara memiliki potensi sumberdaya ikan \pm 500.000 ton/tahun dengan potensi lestarinya diperkirakan sebesar \pm 250.000 ton/tahun. Berdasarkan data statistik perikanan tahun 2015 bahwa produksi perikanan tangkap berdasarkan jenis ikan, yaitu ikan karang 45,730 ton, ikan cakalang dan ikan tongkol 38.412 ton, ikan tuna 9.783 ton dan perikanan laut lainnya 51,07 ton. Produksi perikanan budidaya mencapai $124.548,201$ ton dengan total kawasan budidaya yang sudah dimanfaatkan mencapai 66 \% (Dinas Kelautan dan Perikanan Provinsi Sulawesi Tenggara, 2015). Potensi sumberdaya ikan di perairan menjadi salah satu tumpuan ekonomi daerah. Hal ini disebabkan ikan telah menjadi salah satu komoditas penting, tidak hanya untuk Indonesia tetapi juga masyarakat dunia. Konsumsi ikan masyarakat global akan semakin meningkat 
yang disebabkan oleh meningkatnya jumlah penduduk disertai meningkatnya pendapatan masyarakat dunia, meningkatnya apresiasi terhadap makanan sehat sehingga mendorong konsumsi daging dari pola red meat ke white me at, dan globalisasi menuntut adanya makanan yang bersifat universal, serta berjangkitnya penyakit hewan sumber protein hewani selain ikan sehingga produk perikanan menjadi pilihan alternatif terbaik (Kusumastanto 2008).

Pemanfaatan sumberdaya ikan laut di Sulawesi Tenggara masih terkonsentrasi di perairan pantai. Hal itu disebabkan daerah fishing ground jauh dari perairan Sulawesi Tenggara terutama ikan-ikan pelagis, sehingga nelayan tradisional dan pelaku industry UMKM mengembangkan usaha perikanan tangkap di wilayah pantai khususnya ikan karang. Kondisi demikian berdampak pada berkurangnya hasil tangkapan ikan di perairan pantai dan bahkan beberapa tempat sudah menunjukan overfishing seperti di perairan Kepulauan Saponda Laut dan Perairan Wawonii (Nadia, $d k k ., 2015)$.

Dari aspek perikanan budidaya, kendala bibit menjadi masalah serius yang dihadapi nelayan pembudidaya ikan. Hal tersebut disebabkan pembudidaya ikan masih bergantung pada sumber bibit dari Jawa. Kondisi demikian semakin diperpuruk dengan lemahnya tingkat penanganan bibit ditingkat petani, sehingga bibit yang didatangkan tersebut memiliki tingkat mortalitas yang tinggi hingga mencapai 40-50\% (Yusnaini, 2016). Berdasarkan hal tersebut sangat diperlukan kebijakan pemerintah dalam menangani pengelolaan perikanan yang tepat, terpadu dan berkelanjutan. Salah satu model kebijakan pemerintah adalah menfokuskan program perikanan pada moros maritim.

Kebijakan pembangunan daerah sektor perikanan di Sulawesi Tenggara lebih diprioritaskan pada poros maritim, sehingga keterpaduan sistem pengelolaan laut dicanangkan untuk memacu gerak roda pembangunan khususnya pencapaian ketahanan pangan ikan serta menunjang program pembangunan jangka panjang Sultra Raya 2020. Program pembangunan jangka panjang tersebut ditargetkan meningkatnya dukungan dari perguruan tinggi dan dunia usaha dalam mengembangkan teknologi dan penerapannya pada sentral usaha perikanan terpadu. Dukungan tersebut melalui kerjasama riset terpadu, usaha terpadu dan pengelolaan SDA terintegrasi. Salah satu dukungan riset yang dikembangkan Universitas Haluoleo adalah pengelolaan kawasan laut melalui model agromarine berkelanjutan melalui integrasi teknologi karamba jaring apung (KJA), rumpon dasar ramah lingkungan dan sero sistem kluster.

Model agromarine merupakan solusi untuk mengelola kawasan laut terpadu dan berkelanjutan dari hulu ke hilir. Inovasi teknologi agromarine yang dikembangkan dapat 
meningkatkan jumlah stok ikan pada kawasan fishing ground/spawning ground/nursery ground, sehingga menjadi bank ikan yang menyediakan sumber induk dan bibit ikan serta ketersediaan ikan konsumsi bagi nelayan. Pengelolaan kawasan laut terpadu dengan model agromarine terfokus pada pengelolaan bibit ikan yang diperoleh dari dari hasil tangkapan di sero sistem kluster dan rumpon untuk dikembangkan pada media KJA dan juga peningkatan produksi tangkapan ikan ekonomis untuk keperluan pasar lokal. Berdasarkan hasil penelitian Nadia, $d k k$ (2016) keterpaduan teknologi agromarine yang dikembangkan berkontribusi positif terhadap peningkatan nilai produksi pangan ikan dan telah memberikan peluang bagi implementasi model pengelolaan pada tingkat masyarakat. Selain itu, model yang dikembangkan telah menghasikan informasi fishing ground baik secara spasial maupun temporal dan pengelolaan sumberdaya ikan dari hulu ke hilir.

Sejalan dengan upaya pemerintah untuk peningkatan produksi perikanan, maka sangatlah tepat apabila model agromarine terus dikembangkan secara berkala dan berkesinambungan. Olehnya itu, inovasi sarana produksi dan pengembangan rumpon berbasis KJA dan sero sistem kluster terus dioptimalkan dan pengelolaannya dipastikan tidak akan terjadi konflik kepentingan dalam pemanfaatan kawasan. Olehnya itu, merujuk dari hasil penelitian rumpon yang dikembangkan Universitas Halu Oleo pada program Hi-Link Tahun 2014 tentang rumpon konservasi berbasis riset (Nadia, $d k k$., 2014) dan program Insentif riset Sinas Tahun 2015 tentang pengembangan teknologi rumpon koservasi terpadu yang meliputi rumpon ikan pelagis dan rumpon ikan dasar berbasis ekowisata rumpon (Nadia, $d k k ., 2015$ ), bahwa pengelolaan rumpon harus mengacu pada master plan pembangunan daerah dan daya dukung ekologis seperti dimensi ekologi, dimensi keberlanjutan, dimensi teknologi dan dimensi lingkungan. Hal tersebut telah tertuang pula pada undang-undang konservasi Nomor 5 Tahun 1990 tentang Konservasi Sumberdaya Alam Hayati dan Ekosistemnya dan Peraturan Pemerintah Nomor 60 Tahun 2007 Tentang Konservasi Sumberdaya Ikan.

Dalam implementasinya, model agromarine telah menjadi salah satu desain pengelolaan laut terpadu dalam mengoptimalkan pemanfaatan kawasan berbasis teknologi. Inovasi tersebut, telah menopang kegiatan perikanan budidaya berkelanjutan dan peningkatan produksi perikanan sehingga terwujud ketahanan pangan ikan nasional. Olehnya itu, penelitian ini bertujuan meningkatkan produksi perikanan budidaya berkelanjutan di Karamba Jaring Apung (KJA) dan meningkatkan produksi bibit, pakan dan ikan konsumsi yang tertangkap di sero sistem kluster dan rumpon dasar, sehingga menghasilkan inkubasi bisnis terpadu dalam mendukung pangan ikan di Sulawesi Tenggara. 


\section{BAHAN DAN METODE PENELITIAN}

\section{Teknik Sampling}

Pengambilan data dilakukan selama 4 bulan, yaitu bulan Juni sampai September 2017. Lokasi penelitian adalah desa Puasana perairan Teluk Staring Kabupaten Konawe Selatan Provinsi Sulawesi Tenggara dengan posisi koordinat $122^{0} 40^{\prime} 52.5^{\prime \prime}$ BT dan 04 01' 31.4" LS (Gambar 1).

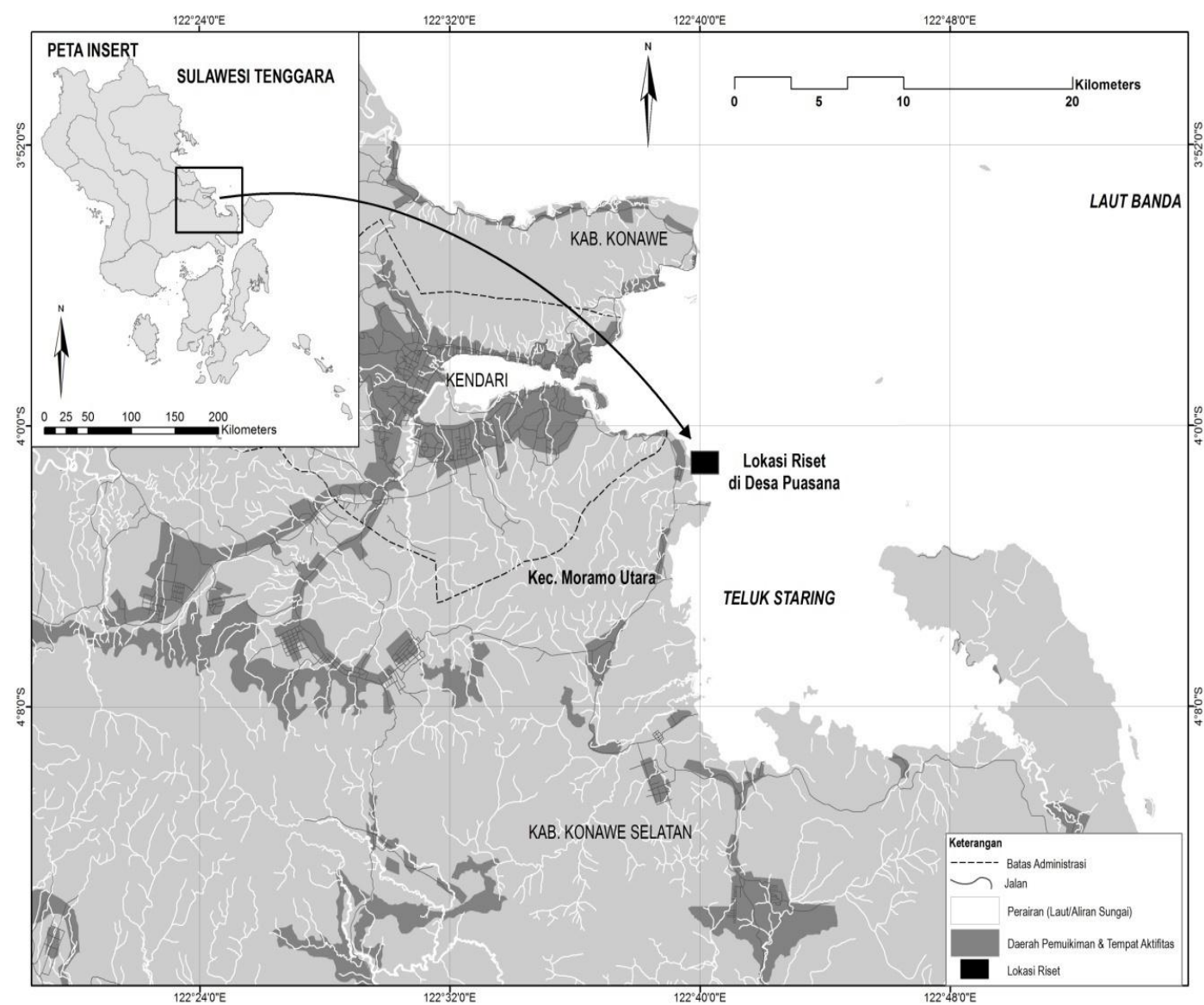

Gambar 1. Peta Lokasi Penelitian Di Desa Puasana Perairan Teluk Staring

Prosedur penelitian ini bersifat eksploratif dan dilakukan dengan mengambil data pada hasil tangkapan di sero sistem kluster dan rumpon dasar. Hasil tangkapan tersebut dikumpulkan dalam kondisi hidup. Selanjutnya dilakukan identifikasi stok bibit ikan dan ikan konsumsi, pengumpulan bibit ikan siap tebar di media budidaya, adaptasi bibit dan pemeliharaan ikan di KJA serta produksi ikan ukuran konsumsi pasca tangkap. Jenis ikan yang tertangkap diidentifikasi dengan mengacu pada beberapa literatur, yaitu Allen et al (2005); Allen et al (2003); Allen, G. (1997); Myers R.F. (1991); Randall et al (1996); Kuiter R.H., and T. Tonozuka (2001), Carpenter dan Niem (2001). 


\section{Analisis Data}

a. Komposisi Jenis dan Kelimpahan Ikan

Parameter yang diamati adalah komposisi jenis (KJ) indeks dan kelimpahan $\left(\mathrm{ind} / \mathrm{m}^{2}\right)$. Perhitungan Komposisi Jenis mengacu pada Greenberg $d k k .$, (1992):

$\mathrm{KJ}=\quad \begin{array}{ll}\mathrm{n} & \mathrm{N}\end{array}$

Keterangan:

$\mathrm{KJ}=$ Komposisi jenis (\%)

$\mathrm{ni}=$ Jumlah individu setiap spesies (ind)

$\mathrm{N}$ = Jumlah individu

Kelimpahan individu ikan dikelompokkan berdasarkan familinya. Kelimpahan suatu organisme dalam suatu perairan dapat dinyatakan sebagai jumlah individu per area (Odum, 1993), dihitung dengan menggunakan persamaan sebagai berikut :

$$
A=\frac{X i}{n i}
$$

Keterangan :

$\mathrm{A}=$ Kelimpahan individu (ind $\left./ \mathrm{m}^{2}\right)$

$\mathrm{Xi}=$ Jumlah individu dari spesies ke-i

$\mathrm{Ni}=$ Jumlah luasan kuadran spesies ke-i ditemukan

b. Tingkat Kelangsungan Hidup

Kelangsungan hidup merupakan persentase ikan hidup hingga akhir pemeliharaan yang dihitung dengan menggunakan rumus berikut (Goddard, 1996):

$$
S R=\frac{(B t / x W t)}{N o} \times 100 \%
$$

Keterangan :

$\mathrm{SR}=$ Persen kelangsungan hidup $(\%)$

$\mathrm{Bt}=$ Biomasa ikan akhir $(\mathrm{kg})$

$\mathrm{xWt}=$ Rata-rata bobot ikan akhir $(\mathrm{kg})$

No = Jumlah ikan awal (ekor) 
c. Perkembangan Produksi Ikan Pasca Tangkap

Perkembangan produksi ikan pasca tangkap dianalisis secara deskriptif dalam bentuk tabel dan diagram. Hasil deskripsi tersebut menggambarkan produktivitas kegiatan perikanan berbasis model agromarine.

\section{HASIL DAN PEMBAHASAN}

\section{Komposisi Jenis dan Kelimpahan}

Jenis ikan yang tertangkap dengan alat tangkap sero dan bubu pada rumpon dasar di perairan Teluk Staring selama penelitian sebanyak 3643 ekor, terdapat 2166 individu diperoleh dari sero sistem kluster dan 1477 diperoleh dari rumpon. Hasil tangkapan tersebut terdiri dari 13 spesies ikan, 1 spesies udang, 2 spesies lobster dan satu spesies kepiting yang berasal dari 11 famili. Sumberdaya ikan tersebut terdiri dari famili Belonidae (1 jenis), famili Carangidae (2 jenis), famili Chandidae (1 jenis), famili Leiognathidae (1 jenis), famili Mugilidae (2 jenis), familiy Mullidae (1 jenis), famili Scombridae ( 1 jenis), famili Serranidae (3 jenis), famili Palinuridae ( 2 jenis), famili Penaeidae (1 jenis) dan famili Portunidae (1 jenis). Berdasarkan teknologi yang digunakan, terdapat 16 jenis ikan tertangkap di sero sistem kluster dan 13 jenis ikan tertangkap di rumpon dasar mengunakan alat bubu bambu. Hampir semua ikan yang tertangkap di sero sistem kluster ditemukan juga di rumpon dasar. Jumlah jenis dan nama lokal ikan yang tertangkap berdasarkan jenis teknologi yang digunakan di lokasi penelitian disajikan pada Tabel 1 dan komposisi jenis ikan berdasarkan jenis teknologi disajikan pada Gambar 2.

Tabel 1. Nama Jenis Dan Jumlah Hasil Tangkapan Ikan Berdasarkan Jenis Teknologi Yang Digunakan Di Lokasi Penelitian

\begin{tabular}{|c|c|c|c|c|c|}
\hline \multirow{2}{*}{ No } & \multirow{2}{*}{ Nama Jenis } & \multirow{2}{*}{ Nama lokal } & \multicolumn{2}{|c|}{ Jumlah Hasil Tangkapan (ind) } & \multirow{2}{*}{$\begin{array}{l}\text { Total } \\
\text { (ind.) }\end{array}$} \\
\hline & & & Sero & Rumpon & \\
\hline A & $\underline{\text { Famili Belonidae }}$ & & & & \\
\hline 1 & $\begin{array}{l}\text { Strongylura leiura } \\
\text { Famili Carangidae }\end{array}$ & Ikan sori & 22 & 77 & 99 \\
\hline 2 & Caranx ignobilis & Ikan kuwe/putih & 1500 & 88 & 1588 \\
\hline 3 & $\begin{array}{l}\text { Scomberoides tala } \\
\text { Famili Chandidae }\end{array}$ & Ikan talang-talang & 2 & 65 & 67 \\
\hline 4 & $\begin{array}{l}\text { Ambassis interruptus } \\
\text { Familiy Leiognathidae }\end{array}$ & Ikan caria & 65 & 43 & 108 \\
\hline 5 & $\begin{array}{l}\text { Leiognathus equulus } \\
\text { Famili Lutjanidae }\end{array}$ & Ikan peperek & 76 & 0 & 76 \\
\hline 6 & Lutjanus rivulatus & Ikan kakap merah & 4 & 77 & 81 \\
\hline 7 & Lutjanus ruselli & Ikan jenaha & 9 & 89 & 98 \\
\hline
\end{tabular}


Famili Mugilidae

$8 \quad$ Valamugil buchanami

Ikan belanak $\quad 32$

0

Familiy Mullidae

9 Upeneus sulphureus

Ikan biji nangka

12

98

Famili Scombridae

10 Rastrelliger kanagurta

Ikan rumah-rumah

212

Famili Serranidae

11 Anyperodon leucogramicus

Ikan kerapu

12 Epinephelus merra

Ikan kerapu

132

13 Cephalapholis miniata

Ikan kerapu

320

Famili Palinuridae

\section{Panulirus Ornatus}

Lobster mutiara

15 Panulirus versicolor

Lobster bambu

Famili Penaeidae

16 Penaeus merguiensis

Udang putih

21

0

Famili Portunidae

17 Portunus pelagicus Kepiting rajungan

102

23

\begin{tabular}{|c|c|c|}
\hline 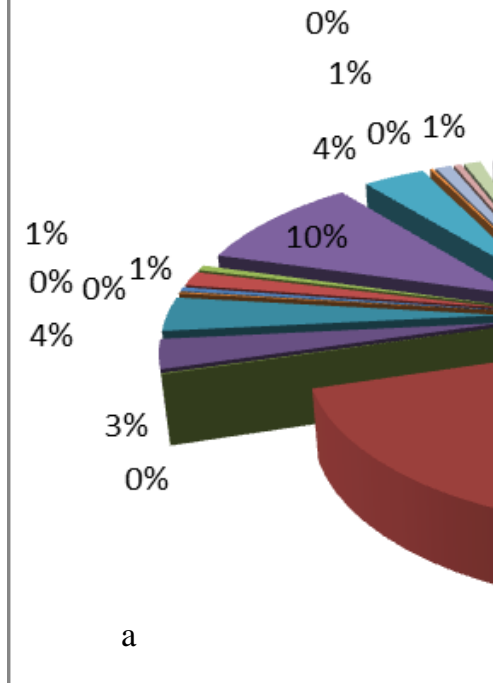 & Sero Kluster & 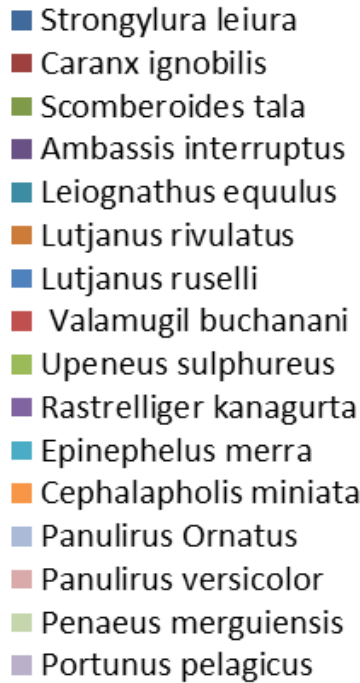 \\
\hline
\end{tabular}




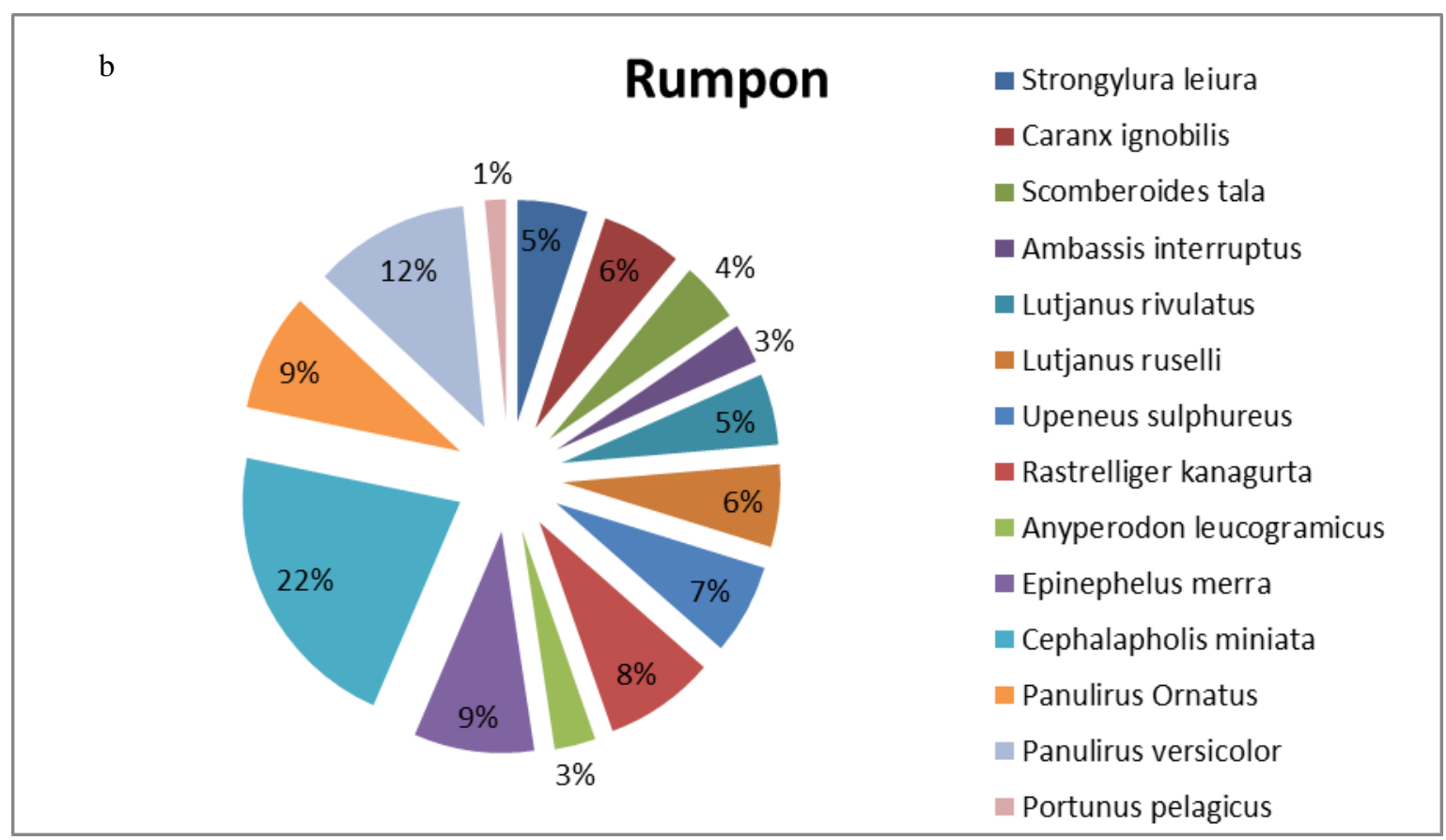

Gambar 2. Komposisi Jenis Ikan Yang Tertangkap Selama Penelitian Berdasarkan Jenis Teknologi

Berdasarkan Tabel 1, diperoleh informasi bahwa famili Carangidae dari jenis ikan C.ignobilis paling banyak ditemukan di lokasi penelitian dengan jumlah 1500 individu, selanjutnya jenis $R$. Kanagurta sebanyak 333 individu dan terendah jenis V.buchanani sebanyak 32 individu. Tingginya jenis C.ignobilis sesuai dengan kalender nelayan pada bulan Juli sampai November adalah musim puncak jenis ikan tersebut dan jenis ikan lain seperti $R$. Kanagurta. Dalam penelitian Nadia, dkk., (2015) di lokasi yang berbeda bahwa musim penangkapan ikan jenis C.ignobilis dan kelompok ikan pelagis lain seperti cakalang dan ikan kembung lelaki adalah bulan September. Pada bulan puncak, ikan tersebut banyak ditemukan di sekitar pantai dan menyukai daerah pantai yang masih terdapat terumbu karang dan ekosistem lamun. Terkait dengan posisi demplot teknologi, lokasi penelitian sangat strategis karena letak sero dan rumpon dasar berada pada daerah transisi antara kawasan terumbu karang dan ekosistem lamun. Kedua daerah tersebut merupakan daerah subur yang menyediakan sumber makanan dan juga tempat untuk reproduksi bagi ikan pelagis dan ikan demersal pada musim Tenggara di bulan Juli sampai November 2017.

Jenis ikan yang berasal dari famili Serranidae seperti E.merra dan C.miniata banyak ditemukan di lokasi penelitian. Kedua jenis ikan ini tergolong ikan target bernilai ekonomis penting yang berasosiasi dengan terumbu karang dan sering pula dijumpai di sekitar ekosistem lamun. Ikan ini banyak tertangkap di sekitar rumpon dasar. Hadirnya ikan-ikan rekruitmen pada rumpon dasar disebabkan konstruksi rumpon dilengkapi pemikat ikan/shelter 
dari daun nipa/daun kelapa. Pemikat tersebut berfungsi menarik ikan untuk berkumpul di sekitar rumpon, dan membentuk jaringan makanan (foodweb). Dengan adanya pemikat dan berkumpulnya ikan menjadikan kegiatan operasi penangkapan ikan menjadi lebih mudah di sekitar rumpon (Nadia, dkk., 2016). Namun, Nahib (2008) mengingatkan bahwa peningkatan biomass yang terdapat di sekitar rumpon bersifat sementara dan tidak menambah jumlah biomass secara keseluruhan. Hal ini juga sesuai pendapat Jaquemet et al. (2010) yang menyatakan bahwa rumpon merupakan ecological trap untuk ikan-ikan rekruitmen ukuran kecil sampai mencapai kematangan gonad. Untuk itu, pemanfaatan rumpon harus dilakukan secara hati-hati.

Ikan-ikan yang hadir di rumpon dasar terdiri atas ikan karang dan ikan pelagis. Kelompok ikan karang lebih mendominasi ikan yang ditemukan di lokasi penelitian. Allen \& Adrim (2003) mengemukakan bahwa jumlah kelompok ikan karang sangat banyak di perairan Indonesia. Daftar jenis hasil review, sebanyak 10 suku utama 56\% dari fauna ikan karang di Indonesia yakni Gobiidae (272), Labridae (178), Pomacentridae (152), Apogonidae (114), Bleniidae (107), Serranidae (102), Muraenidae (61), Syngnatidae (61), Chaetodontidae (59) dan Lutjanidae (43). Ikan-ikan tersebut sangat tergantung dengan keberadaan karang, ketersediaan makanan dan tingkat eksploitasi nelayan. Penurunan jumlah individu di daerah fishing ground diakibatkan oleh menurunnya kualitas terumbu karang yang berfungsi sebagai spawning ground, nursery ground, dan feeding ground bagi ikan karang yang berada di sekitarnya (Frindley and Findley, 2001).

Berdasarkan teknologi yang digunakan, komposisi jenis (KJ) tertinggi ikan yang ditemukan di sero sistem kluster adalah jenis C.ignobilis dengan nilai 69,25\% dan terendah jenis L.rivulatus dengan nilai $0,18 \%$. Komposisi jenis (KJ) tertinggi ikan yang disampling di rumpon dasar adalah jenis C.miniata dengan nilai 21,67\% dan terendah dari jenis kepiting rajungan (P.pelagicus ) dengan nilai 1,56\%. Jumlah ikan ditemukan pada alat tangkap sero cukup melimpah disebabkan oleh sifat dari alat tangkap itu sendiri. Sero merupakan alat tangkap ikan yang dipasang secara tetap di dalam air dan hasil tangkapan ikan dilakukan pada waktu air surut yaitu pagi hari dan atau sore hari (Sudirman dan Mallawa, 2004).

Kategori ikan yang ditemukan di rumpon dasar didominasi ukuran layak konsumsi dan ikan sampling di sero dirioritaskan ukuran bibit dan hampir semua jenis yang ditemukan berkelompok kecil hingga sedang. Setiap jenis ikan yang disampling, tidak dikumpulkan sekaligus dalam satu trip, tetapi dilakukan selama 10 trip. Sehingga, ikan yang terkumpul 
untuk kategori bibit dapat dilakukan secara bertahap sampai mencapai target jumlah tangkapan, sebagaimana disajikan pada Tabel 1 di atas.

Pemanfaatan teknologi berbasis agromarine sangat berkontribusi terhadap penyediaan stok bibit untuk dikembangkan pada media Karamba Jaring Apung (KJA) dan penyediaan stok pangan ikan untuk kelompok ikan ekonomis penting. Dari hasil penelitian sebagaimana disajikan pada Tabel 1 bahwa tidak semua jenis ikan ukuran bibit dikembangkan untuk pembesaran ikan di KJA, tetapi hanya 3 jenis yang dikembangkan untuk keperluan budidaya, yaitu jenis C.ignobilis atau ikan kuwe dengan ukuran 230 gram - 263 gram dan jenis P.ornatus atau lobster mutiara serta jenis P.versicolor atau lobster bambu dengan ukuran 200 gram - 220 gram.

Teknologi sero sistem kluster dan rumpon dasar mampu menopang perikanan berkelanjutan karena dapat menekan biaya produksi terutama penghematan biaya pembelian bibit dan juga pembelian pakan. Ikan-ikan yang tidak bernilai ekonomis dan tidak layak konsumsi dimanfaatkan untuk pakan ikan di KJA. Kontribusi pakan yang ditangkap dari sero dan rumpon mencapai $65 \%$, sementara salah satu faktor produksi yang presentase biayanya besar adalah aspek biaya pakan. Kontribusi pakan ikan segar tersebut sangat efisien dan efektif untuk produktivitas budidaya ikan di KJA.

\section{Pemeliharaan Ikan di KJA}

Model agrimarine merupakan suatu upaya untuk mengoptimalkan pengelolaan sumberdaya ikan berbasis teknologi terpadu. Salah satu aplikasinya adalah pemeliharaan bibit ikan hasil sampling di media KJA. Saat perlakuan adaptasi ikan di KJA, seluruh individu ikan berada dalam kondisi yang sangat baik dan tidak ada ikan yang cacat atau sakit. Selama proses adaptasi, bibit ikan di KJA memiliki tingkat kelangsungan hidup (SR) sebesar 100\%. Tidak ada gejala yang mengkhawatirkan selama adaptasi ikan. Dalam proses pemeliharaan, terdapat ikan yang ditemukan stress dan mati, terutama lobster. Lobster mati karena melakukan moulting dan menjadi sasaran lobster lainnya. Ikan yang dipelihara adalah C.ignobilis atau ikan kuwe dan jenis P.ornatus atau lobster mutiara serta jenis $P$. versicolor atau lobster bambu. Ikan tersebut memiliki persentase kelangsungan hidup yang variatif mulai dari 0 minggu hingga 12 minggu masa pemeliharaan. Tingkat kelangsungan hidup ikan (SR) disajikan pada Gambar 3 . 


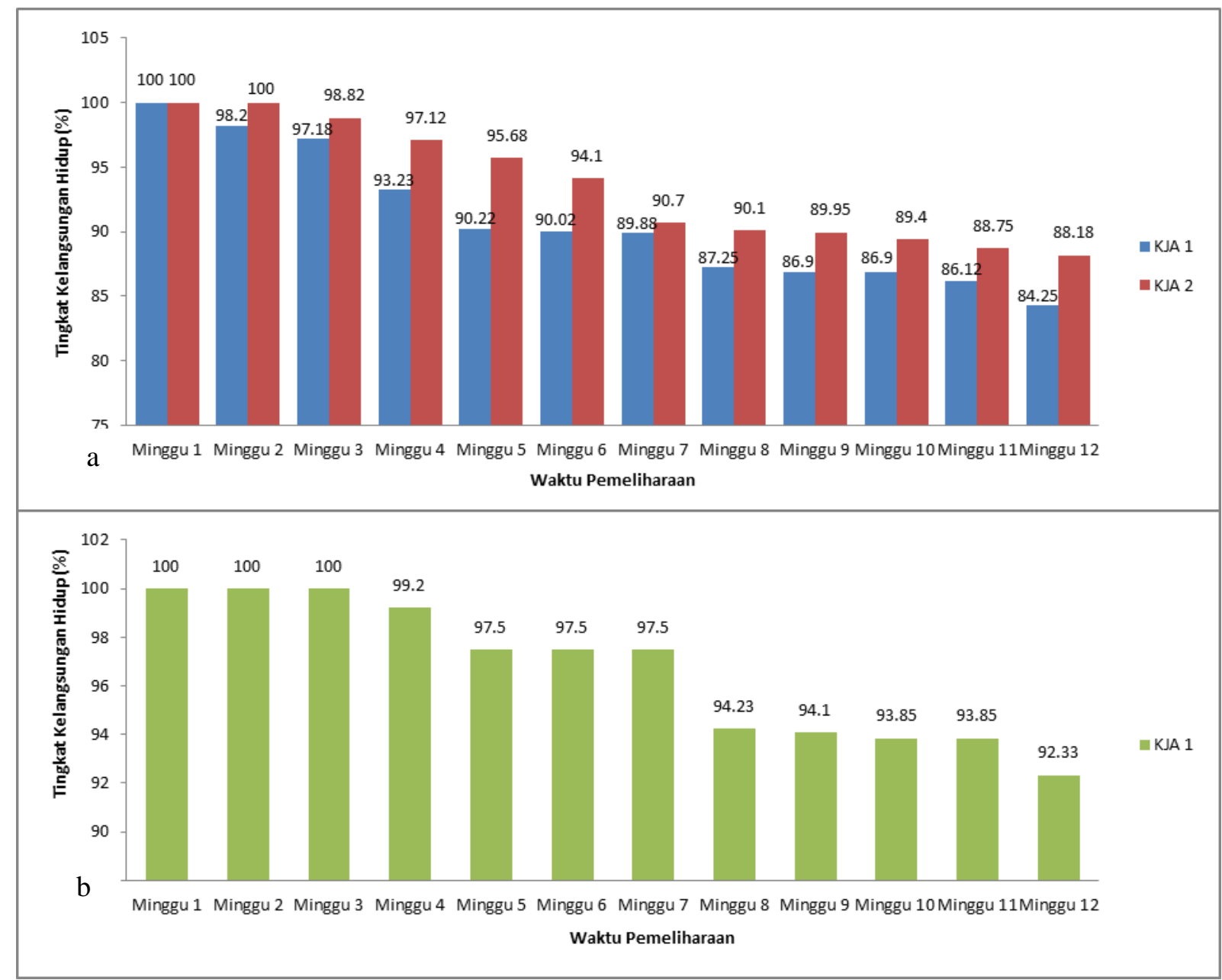

Gambar 3. Tingkat Kelangsungan Hidup (sr) ikan yang Dipelihara di kja: a) Ikan Kuwe (C. ignobilis); b) Lobster

Berdasarkan Gambar 3 bahwa selama pemeliharaan terjadi penurunan jumlah populasi ikan budidaya baik ikan kuwe/ikan putih maupun lobster. Ikan kuwe/putih mulai terjadi kematian pada minggu kedua sedangkan lobster terjadi kematian pada minggu ketiga. Berkurangnya populasi ikan dan lobster yang dipelihara di KJA karena factor kematian alami akibat terjadi stress tertabrak oleh ikan lain dan juga adanya pemangsaan pada lobster yang mengalami proses moulting. Persentase tingkat kelangsungan hidup ikan (SR) yang dipelihara di KJA lebih tinggi lobster dibandingkan ikan putih. SR ikan kuwe/ikan putih mencapai 84,25 - 88,15\% dan SR lobster mencapai 92,33\%. Nilai kelangsungan hidup tersebut tergolong tinggi untuk kategori ikan budidaya di KJA.

Tingginya nilai SR ikan yang dipelihara di KJA, baik ikan kuwe/ikan putih maupun lobster disebabkan pakan yang digunakan dalam penelitian ini adalah ikan segar yang diperoleh dari hasil tangkapan di sero sistem kluster dan rumpon dasar. Selain itu, adanya 
daya dukung perairan di lokasi pemeliharaan. Selama penelitian, data fisika-kimia perairan yang diukur memiliki nilai baku mutu yang masih sesuai dengan standar baku perairan untuk budidaya. Nilai suhu berkisar antara $28-31,8{ }^{\circ} \mathrm{C}$ dan standar baku perairan untuk budidaya KJA berkisar $26,5-30^{\circ} \mathrm{C}$. Namun, kisaran suhu tersebut cenderung konstan dan menurut Sudjiharno dan Winanto (1998) perubahan suhu yang cukup ekstrim akan berpengaruh terhadap proses metabolisme atau nafsu makan ikan. Selama penelitian tidak terjadi perubahan suhu yang ekstrim, sehingga faktor suhu masih dianggap layak untuk dilaksanakannya budidaya ikan kuwe/ikan putih dan lobster. Kecepatan arus pada saat penelitian berkisar antara $0,015-0,039 \mathrm{~m} / \mathrm{s}$. Nilai tersebut sesuai dengan standar baku perairan untuk budidaya ikan di KJA dengan kisaran kecepatan arus 0,2-0,3 m/s.

\section{Produksi Ikan Konsumsi Pasca Tangkap}

Produksi ikan yang dihasilkan dari penerapan model agromarine memperlihatkan perkembangan yang sangat baik. Berdasarkan data produksi ikan selama bulan Juli sampai September 2017 bahwa trend produksi ikan terus meningkat. Data produksi ikan berkisar $380,5 \mathrm{~kg}$ - $560 \mathrm{~kg}$, pada bulan Juli sebesar 380,5 kg, bulan Agustus sebesar 477,8 kg dan bulan September sebesar $560 \mathrm{~kg}$. Produksi ikan tersebut diperoleh dari penggabungan nilai produksi ikan yang tertangkap di sero dan rumpon dasar. Perkembangan data produksi ikan di lokasi penelitian disajikan pada Gambar 4.

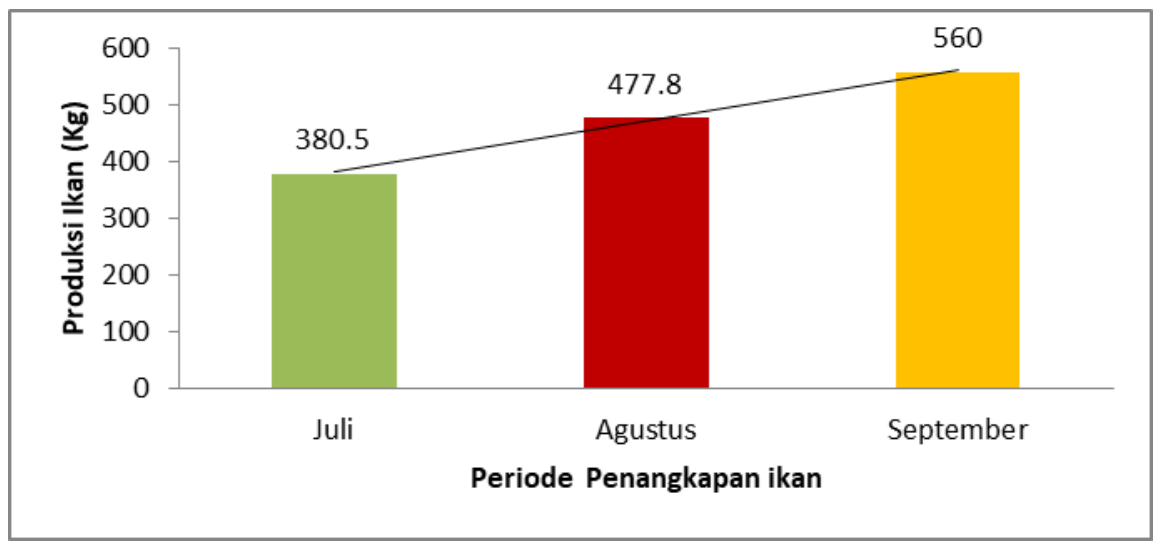

\section{Gambar 4. Total Produksi Ikan Yang Tertangkap Di Lokasi Penelitian}

Dampak yang ditimbulkan dengan adanya rumpon dasar adalah ikan semakin dekat ke arah pantai dan ikan cenderung berkumpul di sekitar rumpon. Begitupula dengan teknologi sero sistem kluster berperan untuk menggiring ikan agar terhimpun dalam daerah bunuhan sero. Keberadaan ikan dalam daerah sero disebabkan karena adanya sekelompok ikan yang mengejar mangsa dan juga mencari ketersediaan makanan yang cukup. Ikan-ikan yang 
terjebak dalam daerah bunuhan sero tidak dapat keluar dari lingkaran sero. Salah satu keunggulan teknologi ini adalah mampu menghimpun stok bibit dan juga ikan ukuran konsumsi yang tergolong ekonomis penting dan non ekonomis.

Terjadinya peningkatan jumlah hasil tangkapan di lokasi rumpon dasar dan sero sistem kluster disebabkan 3 faktor, yaitu pertama, faktor dampak rumpon sangat positif terhadap daya tarik ikan; kedua, penggunaan alat tangkap sero yang sesuai; ketiga, frekuensi penangkapan ikan mengikuti pasang surut. Ketiga faktor tersebut sangat dominan dalam penentuan jumlah produksi tangkapan menggunakan inovasi teknologi. Dari aspek lain, model pengelolaan ikan dengan mengintegrasikan fungsi teknologi maka dihasilkan nilai produksi ikan meningkat dan juga nilai stok ikan terus berkelanjutan.

\section{KESIMPULAN}

Kesimpulan penelitian ini adalah teknologi sero telah berhasil menghimpun bibit ikan kuwe (Caranx sp.) sebanyak 1500 ekor, dari hasil tangkapan di rumpon dasar telah berjhasil menghimpun bibit lobster sebanyak 180 ekor dengan ukuran 200 - 220 gram/ekor yang diperoleh dari alat tangkap bubu bambu, tingginya SR ikan putih mencapai 84,25 - 88,15\% dan SR lobster mencapai 92,33\%,, produksi ikan konsumsi pasca tangkap berkisar 380,5 $560 \mathrm{~kg} / \mathrm{bulan}$. Model agromarine berkontribusi untuk optimalisasi produksi dan minimalisasi biaya produksi budidaya serta meningkatkan pangan ikan berkelanjutan.

\section{UCAPAN TERIMA KASIH}

Penelitian di Perairan Teluk Staring Kabupaten Konawe Selatan terselenggara berkat kerjasama Lembaga Penelitian dan Pengabdian Kepada Masyarakat Universitas Halu Oleo (LPPM UHO) dengan Kemenristekdikti melalui program Insentif Riset Sinas Pratama Individu. Olehnya itu, penulis menyampaikan terimakasih yang sebesar-besarnya kepada kedua lembaga tersebut atas bantuan dana dan fasilitas yang telah digunakan selama penelitian. Selanjutnya, penulis menghaturkan terimakasih tak terhingga kepada kepala desa Puasana di wilayah penelitian dan segenap tim peneliti yang selalu bekerjasama dalam pelaksanaan penelitian sampai pada penulisan artikel ini.

\section{DAFTAR PUSTAKA}

Allen, G.R., R. Steene, P. Humann, and N. Deloach. 2005. Reef Fish Identification, Tropical Pacific.New World Publications, Inc. El Cajon CA. 480 pages. 
Allen, G.R., R. Steene, P. Humann, and N. Deloach. 2003. Reef Fish Identification Tropical Pacific, Australia: New World Publications.

Allen, G. R. 1997. Marine Fishes of Tropical Australia and South East Asia.A FieldGuide for Angler and Diver.Western Australia Museum.

Carpenter, K.E. and Niem, V.H. 2001a. FAO species identifi cation guide for fi shery purposes. The living marine resources of the western central pacifi c. Volume 4. Bony fi shes part 2 (mugilidae to carangidae). Rome, FAO. Pp. 2069-2790.

Carpenter, K.E. and Niem, V.H. 2001b. FAO species identifi cation guide for fi shery purposes. The living marine resources of the western central pacifi c. Volume 5. Bony fi shes part 3 (menidae to pomacentridae). Rome, FAO. Pp. 2791-3380.

Carpenter, K.E. and Niem, V.H. 2001c. FAO species identifi cation guide for fi shery purposes. The living marine resources of the western central pacifi c. Volume 6. Bony fi shes part 4 (labridae to latimeriidae), estuarine crocodiles, sea turtles, sea snakes and marine mammals. Rome, FAO. Pp. 3381-4218.

Goddard, S. 1996. Feed Management in Intensive Aquaculture. Chapman and Hall, New York. p : 172.

Reenberg, 1992 Standar Metods for the Examination of Water and Wastewater for 4th Edition. American Publich Health Asosiation.

Kuiter RH dan Tonozuka T. 2001. Photo guide Indonesian reef fishes. Zoonetics. Australia. 893 h.Mayr, E. and P.D. Aslock. 1991. Principles of systematic zoology.2nd. Ed. McGrawHill, Inc.

Nadia, L.A.R, Abdullah, Takwir, A, dan Balubi. 2016. Pengelolaan Rumpon Berbasis POKJAMAS Untuk Meningkatkan Stok Ikan dan Penguatan UMKM Nelayan. Prosiding Seminar Nasional ISBN 978-979-796-223-4. Hal 168-177.

Nadia, .L.A.R., Abdullah, A. Takwir , Salwiyah dan I. Male. 2016. Management of sustainable fisheries in staring bay through the integration of shallow fads and new bioreeftech technology based on community working group (pokjamas) to improve livelihood and conservation. Final Report. LPPM UHO-USAID. 190 hal.

Nadia,L.A.R., Abdullah dan A. Takwir. 2015. Peningkatan produksi hasil tangkapan komoditas unggul perikanan (ikan karang, kepiting rajungan dan cumi-cumi) berbasis paket teknologi rumpon terpadu ramah lingkungan dan peningkatan mutu produk hasil tangkapan dengan sistem rantai dingin sebagai penguatan kemandirian sektor UMKM di pesisir Kabupaten Konawe. Laporan Akhir Program Iptekdalipi, Universitas Halu Oleo.

Nadia. L.A.R., Abdullah, A. Takwir dan M. Balubi. 2014. Rumpon konservasi berbasis riset di perairan Laut Kabupaten Konawe. Laporan Akhir Program Hi-Link, Universitas Halu Oleo.

Odum, E.P. 1993. Dasar-Dasar Ekologi. Edisi ketiga .Gajah mada University Press. Jogjakarta. 